\title{
Drinking Water from Water Dispenser: Estimation of Cancer Risk for Consumer in Northeastern Region, Thailand
}

\section{Sir,}

Water is necessary for life, and human beings have to drink water every day. The contamination in drinking water becomes a big public health concern. At present, the use of chlorination plays an important role in control of microbial contamination in drinking water. Nevertheless, the new concern is on the chemical contamination. The great concern is on the by-product from the disinfection process of the water. ${ }^{[1]}$ The possibility that the chemical contamination in drinking water can induce carcinogenesis becomes an interesting issue in medical oncology. According to the animal model study, it was approved that "dibromoacetonitrile" in the drinking water could result in carcinogenesis..$^{[2,3]}$ Another important chemical, a by-product from disinfection process is "dibromochloromethane." The dibromochloromethane is proved for relationship with hepatic carcinogenesis..$^{[4]}$

In human, the risk of cancer induced by exposed to chemical contamination in drinking water is an interesting topic. Here, the authors estimated the cancer risk due to exposure to dibromochloromethane contamination in drinking water from water dispenser in the Northeastern region, Thailand. In this study, the calculation for the cancer risk was performed using the basic data on individual lifetime cancer risk for dibromochloromethane. The calculation is based on the basic equation as described in the previous report on cancer risk estimation for exposure to dangerous chemical, ${ }^{[5]}$ "individual lifetime cancer risk $=$ concentration of contaminated dibromochloromethane in drinking water $\times$ lifetime unit risk factor."
According to a recent survey on drinking water samples collected from water dispenser in Northeastern region of Thailand by Local Thai Northeastern Medical Science Center (http://budgetitc.dmsc.moph.go.th/research/ pdf/20152. pdf), 39 from 55 (70.9\%) samples have dibromochloromethane contamination with average level $10.94 \mathrm{ng} / \mathrm{mL}$. Hence, for each individual after adjustment for the possibility to get exposure (70.9\%), the final exposed concentration will be $7.76 \mathrm{ng} / \mathrm{mL}$. Focusing on the lifetime unit risk factor, according to the US Environmental Protection Agency (https://cfpub.epa.gov/ncea/iris/iris documents/documents/subst/0222_summary.pdf), this value is equal to $2.4 \times 10^{-6} \mathrm{~L} / \mathrm{g}$. Based on the described data, the calculated estimated individual lifetime cancer risk due to drinking water from water dispenser in the study setting is equal to $1.86 \times 10^{-11}$ or this means in a lifetime of a people who drink the water. At present, the water dispenser becomes a widely machine in several communities in Thailand and other nearby tropical countries where the weather is usually hot. Without control, the problem on the safety of the water from water dispenser can be expected, and it can be the hidden cause of emerging cancer among the local population in the future. Nevertheless, the study showed that the estimated calculated cancer risk due to determined amount of contamination is extremely low (about 19 cases per trillion). Based on the present water disinfection technology and the observation on the drinking water from water dispenser, drinking the water should be safe and free of risk for carcinogenesis due to dibromochloromethane contamination. 
Nevertheless, further assessment and cancer risk estimation regarding the contamination due to other chemicals in the drinking water is still required. Finally, the possible unwanted health effect due to the new generation of water dispenser that can desalinate should be noted. Regardless the water contamination, the desalinating process is proved to cause electrolyte disturbance if one drink the water and might further induce cancer. ${ }^{[6]}$

\section{Financial support and sponsorship}

Nil.

\section{Conflicts of interest}

There are no conflicts of interest.

\section{Beuy Joob, Viroj Wiwanitkit ${ }^{1}$}

Sanitation 1 Medical Academic Center, Bangkok, Thailand, 'Department of Medical Science, Faculty of Medicine, University of Niš, Niš, Serbia

\author{
Address for correspondence: \\ Dr. Beuy Joob, \\ Sanitation 1 Medical Academic Center, Bangkok, Thailand. \\ E-mail:beuyjoob@hotmail.com
}

\section{References}

1. National Toxicology Program. Toxicology and carcinogenesis studies of dibromoacetonitrile (CAS no 3252-43-5) in F344/N rats and $\mathrm{B} 6 \mathrm{C} 3 \mathrm{~F} 1$ mice (drinking water studies). Natl Toxicol Program Tech Rep Ser 2010;1:1-193.

2. Villanueva CM, Castaño-Vinyals G, Moreno V, Carrasco-Turigas G, Aragonés N, Boldo E, et al. Concentrations and correlations of disinfection by-products in municipal drinking water from an exposure assessment perspective. Environ Res 2012;114:1-11.
3. Bull RJ, Meier JR, Robinson M, Ringhand HP, Laurie RD, Stober JA, et al. Evaluation of mutagenic and carcinogenic properties of brominated and chlorinated acetonitriles: By-products of chlorination. Fundam Appl Toxicol 1985;5:1065-74.

4. National Toxicology Program. NTP toxicology and carcinogenesis studies of chlorodibromomethane (CAS no 124-48-1) in F344/N rats and $\mathrm{B} 6 \mathrm{C} 3 \mathrm{~F} 1$ mice (Gavage studies). Natl Toxicol Program Tech Rep Ser 1985;282:1-74.

5. Joob B, Wiwanitkit V. Estimation of cancer risk due to exposure to lead contamination in Thai ayurveda products. Indian J Cancer 2015;52:550.

6. Nriagu J, Darroudi F, Shomar B. Health effects of desalinated water: Role of electrolyte disturbance in cancer development. Environ Res 2016;150:191-204.

This is an open access journal, and articles are distributed under the terms of the Creative Commons Attribution-NonCommercial-ShareAlike 4.0 License, which allows others to remix, tweak, and build upon the work non-commercially, as long as appropriate credit is given and the new creations are licensed under the identical terms.

\begin{tabular}{|l|l|}
\hline \multicolumn{2}{|c|}{ Access this article online } \\
\hline Quick Response Code: & Website: \\
& www.ijmpo.org \\
\cline { 2 - 2 } & DOI: \\
\hline
\end{tabular}

How to cite this article: Joob B, Wiwanitkit V. Drinking water from water dispenser: Estimation of cancer risk for consumer in Northeastern Region, Thailand. Indian J Med Paediatr Oncol 2018;39:554-5.

C 2018 Indian Journal of Medical and Paediatric Oncology | Published by Wolters Kluwer - Medknow 